In Focus

\title{
From Dusk till "DAU": the Rise of Heterotopic Cinema in the Times of Pandemic
}

$\$$ sciendo

ALEXANDRE ZAEZJEV, University of Geneva, Switzerland; email: alexandre.zaezjev@etu.unige.ch 


\section{ABSTRACT}

The release of Ilya Khrzhanovsky's megalomaniacal cinematic project $D A U$ coincided with the global Covid-19 pandemic. With festivals postponed and public screenings no longer possible, Khrzhanovsky moved his project online, integrating the unprecedented experience of the global lockdown and quarantine into the cinematic universe of DAU. Using the concept of heterotopia devised by French philosopher Michel Foucault, this paper examines the ways in which self-isolation altered the conditions of spatio-temporal engagement with $D A U$. Ultimately, the paper presents an original theoretical model of heterotopic cinema to demonstrate that confinement is precisely what allows Khrzhanovskiy's artistic method to fully function.

\section{INTRO}

With film productions shut down, festivals postponed, and movie theatres operating well below full capacity, the short-term effect of the Covid-19 pandemic on the film industry is akin to a near-death experience. While the industry as a whole strives for survival, some filmmakers were able to approach the global crisis creatively and explore the experience of confinement through artistic means. Such is the case of Russian director Ilya Khrzhanovsky and his recent project DAU - an ambitious cinematic endeavour, comprised of "over a dozen feature films, several dramatic series, documentaries, and an innovative digital platform" (Phenomen Trust 2019). Before the pandemic hit Europe, Khrzhanovky had a chance to premiere DAU in Paris and Berlin, receiving an award "for Outstanding Artistic Contribution" at the Berlinale 2020. As it became obvious that no other public screenings will take place in the near future, the filmmaker decided to move DAU online.

\begin{abstract}
"The project's release on the internet is taking place now," explained the filmmaker in Summer 2020, "in the era of the pandemic, when the whole world is under house arrest, like behind the Iron Curtain, but in an even smaller space, in people's own apartments, in complete isolation, which in itself looks like a hellish, total performance." (Cronk 2020) On the official website, Khrzhanovsky further defines DAU as "The first cinematic project about isolation, filmed in isolation, for people in isolation" (Dau Cinema 2020). The notion of isolation thus emerges as an important aspect of DAU production and reception alike. Using the theoretical concept of heterotopia formulated by French philosopher Michel Foucault, the present paper examines the implications of the pandemic and the condition of confinement for the release of DAU online. Furthermore, it devises an original theoretical model of heterotopic cinema to demonstrate that confinement is actually what allows for $\mathrm{Khr}$ zhanovskiy's artistic method to fully function; in other words, that an enhanced experience of $D A U$ is predicated upon the viewing conditions dictated by the pandemic.
\end{abstract}




\section{THEORETICAL CONTEXT} AND LITERATURE REVIEW

In a lecture entitled Of Other Spaces (1967), Foucault developed the concept of "heterotopia" describing it as a place that physically exists within a known world but that is also phenomenologically different from it, a place that disrupts the continuity and regularity of our spatio-temporal perception. Literally meaning "sites of otherness," heterotopias can be understood as places of "culturally recognized and codified "nonreality"' (Groys 2008: 31) that "inject alterity into the sameness, the commonplace, the topicality of everyday society" (Dehaene, De Cauter 2008: 4). In contrast with the dualistic "utopian/dystopian formula prevalent in the 'modernist' era" (Näripea 2014: 121), heterotopia is "a kind of postmodern spatial alterity" (Knight 2017: 5), a theoretical model that focuses on a hybridised, fragmented and oscillating nature of a particular spatial structure or experience. Examples of heterotopias provided by Foucault include cemeteries, theatres, cinemas, museums, fairs, brothels, as well as retirement homes, psychiatric institutions, and prisons, to name just a few.

Foucault (1967) uses these examples to formulate the six principles of heterotopology, "a sort of systematic description" of heterotopias: (1) heterotopias are omnipresent but not universal and can take varied forms, such as crisis heterotopias and heterotopias of deviation; (2) heterotopias' functions are not ontologically predetermined and can be subject to change; (3) heterotopias juxtapose in a single real place two or more spaces that might be in and of themselves incompatible; (4) heterotopias create an absolute break with the everyday time; (5) access to heterotopias is restricted and requires rites of passage; and (6) heterotopias are physically isolated from but functionally related to the remaining outside space. While Foucault does list these six principles of heterotopology, the concept itself remains subject to scholarly debates, attracting various interpretations and adaptations, making the heterotopia "a familiar, albeit an ambiguous trope in critical thought on spatiality" (Knight 2014: 8).

The concept of heterotopia has been widely deployed in media studies. Hye-jin Chung (2018) explored the Foucauldian idea to devise his own concept of a "media heterotopia" - "a digitally enhanced audio-visual realm of representation that superimposes layers of diverse spatialities and temporalities" (ibid. 37). A film and television theorist Francesco Casetti (2015) adapted the concept of heterotopia to the digitally-mediated condition of contemporary cinema. Casetti introduced the term "hypertopia" to describe the spatial structure of cinema consumed via a multitude of portable screens, a kind of extraverted heterotopia, a space of otherness that "no longer asks to go to it; [but] comes to me, reaching me wherever I am" (ibid. 144). The notion of heterotopia has also been mobilized in the study of "database cinema" conceptualising the "database" as a virtual heterotopia that replaces the chronological linearity of time with the non-linear logic of space. Arpin-Simonetti (2014), for instance, used the Foucauldian model to build his analysis of Peter Greenaway's Tulse Luper Suitcases (2003) - the most ambitious example of the "database cinema" before DAU, as Lev Manovich, who coined the term, has recently pointed out himself (Dau Haus 2020c).

While both Greenaway's and Khrzhanovsky's works are examples of independent experimental cinema, a heterotopic reading also finds its way into the studies of popular film. Eva Näripea (2014), for instance, examined several Polish-Estonian coproductions directed by Marek Piestrak (1979, 1987, 1992). Emphasizing the "otherness" of places depicted by Polish director, the author demonstrated how cinematic heterotopias provided a voice to subversive cultural discourses silenced in the Soviet Union and its satellite states. Soviet cinematic legacy is further examined through a heterotopic lens in several other works (Mazierska 2012, Näripea, Cederlöf 2015) with Andrey Tarkovsky's oeuvres (1972, 1979) often being the focus of such studies 

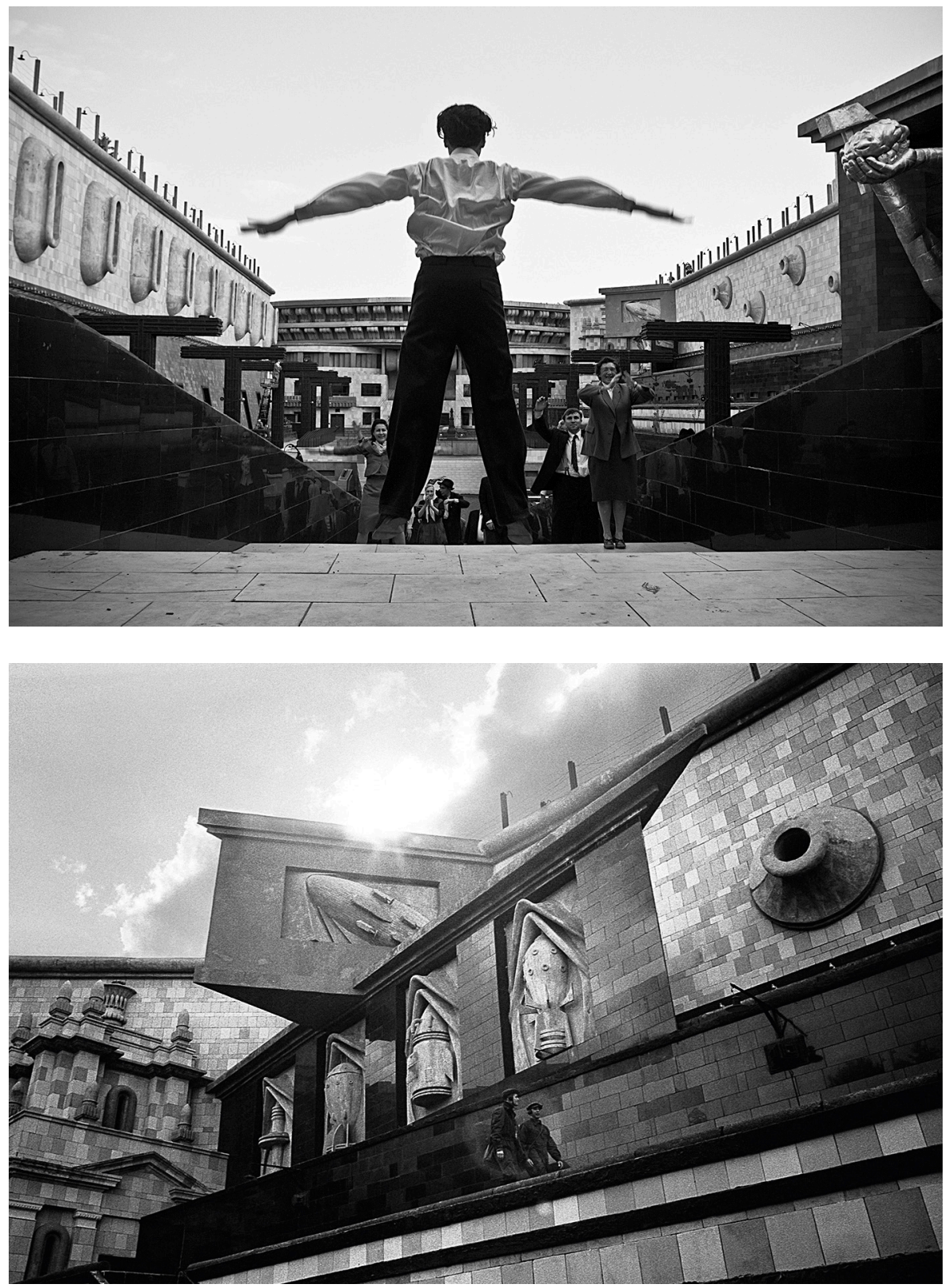

FIGURE 1. DAU film set - the Institute

(photo: Olympia Orlova, DAU press kit, Phenomen IP 2019).

FIGURE 2. DAU film set - the Institute

(photo: Jörg Gruber, DAU press kit, Phenomen IP 2019). 
(Ivakhiv 2011, Näripea 2013, Burlacu 2015). More recent examples of films investigated using the concept of heterotopia include George Miller's Mad Max franchise (Corbett 2017), Stephen Daldry's The Hours (Zhao, Öner 2018), Todd Haynes's Carol (Smith 2018), and Ben Wheatley's High-Rise (Klein 2019).

It is important to emphasize, however, that this extensive body of scholarship focuses on cinematic heterotopias, rather than on heterotopic cinema - a distinction that is crucial for our understanding of DAU. While research on cinematic heterotopias engages primarily with "heterotopias generated by the spatially and temporally multilayered on-screen cinescapes and constructed plots" (Näripea 2014: 123, italics added), a study on heterotopic cinema explores how heterotopias generate spatially and temporally multilayered conditions of both film production and reception.

Beginning with Foucault's (1967) own account of movie theatres, heterotopias of reception gained extensive scholarly attention in film and media studies (Kuhn 2004, Bruno 2002, Casetti 2015). Heterotopias of production, however, are much rarer in cinema, with a few notable examples in the experimental film - for instance, those of Andy Warhol $(1965,1966)$ and Jacques Rivette (1971), but most markedly, David Watkins' Punishment Park (1971) and, in particular, La Commune - Paris, 1871 (2000). As the present paper demonstrates, $D A U$ embodies both heterotopias of production and reception, which constitutes Khrzhanovsky's original artistic strategy and makes DAU a prominent example of heterotopic cinema.

\section{HISTORICAL CONTEXT}

DAU was conceived in 2006 as a rather conventional biopic on a Soviet science genius Lev Landau (1908-1968) with a modest budget allocated by several European funding agencies. In 2007, however, Khrzhanovsky came across a wealthy private sponsor and the budget for the project rocketed, ${ }^{1}$ allowing the thirty-two-year-old

For a comprehensive account of the role of private sponsors behind DAU see Pinkham (2020). independent filmmaker to transform DAU into an unprecedented folie des grandeurs.

In 2009, a gargantuan ensemble of pseudo-Stalinist architecture - the socalled "Institute" - was built in Kharkiv, Ukraine, specifically for Khrzhanovsky's DAU. Occupying an area comparable to an average university campus, the Institute was modelled after a typical Soviet "science city" of the mid-twentieth century - an area of secret research facilities and living quarters for scientists closed off from the outside world (Lappo, Polian 2007: 1229). Designed as an architectural extravaganza, a postmodernist pastiche of neoclassicism, constructivism, and expressionism, the DAU film set included fully operational laboratories, two apartment blocks, interrogation cells, as well as a diner, a press office, and an administrative building (Figures 1 and 2).

Having constructed the largest film set in the history of European cinema, Khrzhanovsky used it to stage an immersive cinematic experiment that lasted for almost three years. The filmmaker hired no professional actors, had no script, no rehearsals, and no reshoots. Instead, Khrzhanovsky invited volunteers from all over the world to spend weeks, months, and sometimes years in the Kafkaesque universe of Soviet totalitarianism that he thoroughly (re)created on the film set. A cast of over 400 principal actors and 10,000 extras included both ordinary people and famous contemporary artists like Marina Abramovic, opera and theatre directors Peter Sellars and Romeo Castellucci, conductor Teodor Currentzis, Nobel Prize winner in physics David Gross, as well as many other prominent scientists including Carlo Rovelli, Andrey Losev, Dmitry Kaledin, to name just a few (Figure 3). Provided with historical costumes and props residents of the Institute were asked to renounce any connections to contemporary reality. They were required to leave behind any personal objects and electronic devices, as well as to avoid topics of discussion and cultural references that did not fit the fictional timeline of DAU.

"The Institute existed within a parallel spatial and temporal universe: a meticulous 

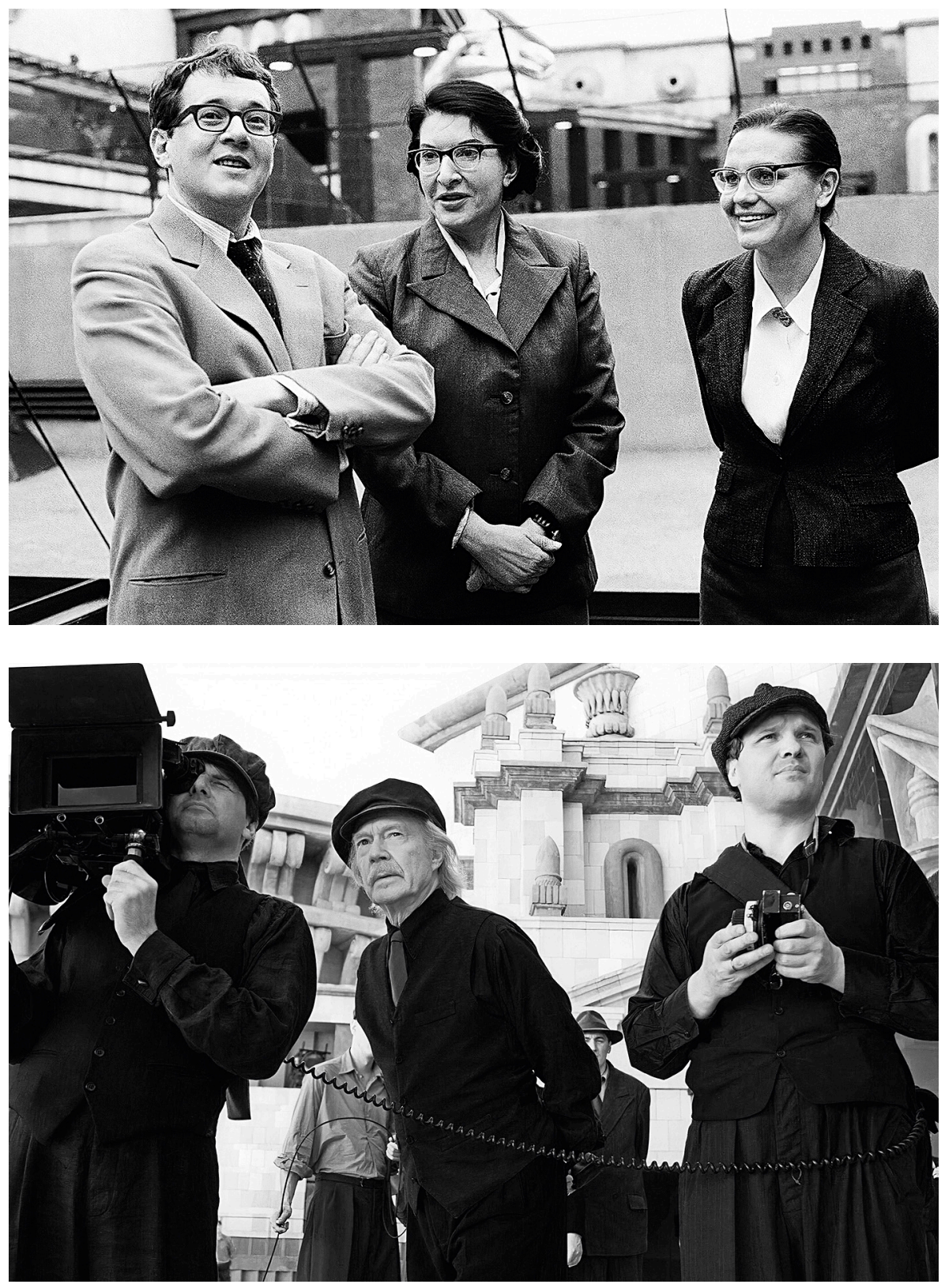

FIGURE 3. Ilya Khrzhanovsky (left) and Marina Abramović (center) inside the Institute (photo: Phenomen IP 2019).

FIGURE 4. Jürgen Jürges (center) with the filming crew inside the Institute (photo: Phenomen IP 2019). 
historical reconstitution spanning the years 1938 to 1968," explains the official DAU brochure (Macnab 2019). Immersed in the world of DAU, participants were genuinely living the everyday lives of their characters. Real-life barmaids worked as waitresses at the Institute's diner, real-life ex-KGB officers surveilled the Institute and its residents, real-life journalists published a newspaper at the Institute's press office. Finally, reallife scientists conducted real research in the laboratories of the fictional Institute which, in a very meta-referential spirit of Charlie Kaufman's Synecdoche, New York (2008), operated like one giant laboratory with hundreds of participating subjects.

To transpose the complex experience of DAU into the cinematic realm, Khrzhanovsky invited a celebrated German cinematographer Jürgen Jürges. $35 \mathrm{~mm}$ film was used to shoot all 700 hours of footage because, as Jürges explains, "that's the closest thing to how the movies were made at the time" (Dau Haus 2020 b). In 2011, after almost three years of documenting life inside the Institute, the production came to an end with a ritualistic destruction of the entire DAU film set, followed by a massive open-air rave on its ruins. It took another seven years for Khrzhanovsky and his team to complete the post-production of his magnum opus. With 10 out of the total 14 feature films being released online as of September 2020, DAU is described as "an ongoing project" (Dau Cinema 2020). The creation of an innovative digital platform, DAU Digital, featuring all 700 hours of footage, 8,000 hours of dialogues, 500,000 set photographs, and extensive descriptive metadata, was announced in 2019 without mentioning a specific release date.

\section{HETEROTOPIA DAU}

Having provided a general overview of the DAU production process, we will now demonstrate how the Institute meets all six principles of heterotopology ${ }^{2}$ and, by Michel Foucault (1967) were summarized in the first section. Hereafter, each of the principles will be referred to by its corresponding number. therefore, constitutes a heterotopia. Access to the territory of the Institute was restricted (Principle 5). The Institute acquired the status of heterotopia for a limited period of time and was destroyed after the filming was over (Principle 2). It had "a function in relation to the rest of space" (Foucault 1967: 22); that of a film set for producing 700 hours of multimedia content (Principle 6). The Institute was inhabited by "individuals whose behaviour is deviant in relation to the required mean" (ibid. 18) (Principle 1), namely, present-day scientists, artists, and other participants of Khrzhanovsky's project absorbed in the parallel temporal dimension of DAU (Principle 4).

Foucault's third principle is particularly important for the understanding of the mechanism of heterotopia and thus warrants an in-depth discussion. According to this principle, heterotopias juxtapose "in a single real place several spaces, which may be incompatible" (ibid. 19). Heterotopias conflate "private space and public space, cultural space and useful space, the space of leisure and that of work" (ibid. 16) into single "spaces of otherness" with peculiar attributes of their own. The language Foucault uses to describe heterotopias "juxtaposed spaces," "contradictory sites" clearly points to a certain kind of tension that exists between the elements, a tension that is resolved by and within heterotopia. This heterogeneous aspect of heterotopic spaces can be illustrated with the Necker cube effect - a graphic representation of the so-called multistable perception: "the spontaneous alternation between two or more perceptual states that occurs when sensory information is ambiguous" (Sterzer 2009). In the scheme provided below, the paradox of two conflicting perspectives

(Figure 5: points 1 and 2) onto a single object (Figure 5: point 3) is resolved through an optical illusion that does not privilege one orientation over the other but allows for an oscillating, yet simultaneous, existence of both.

DAU follows a similar multistable logic: the fictional universe of a motion-picture "the cultural space" of the seventh art - 


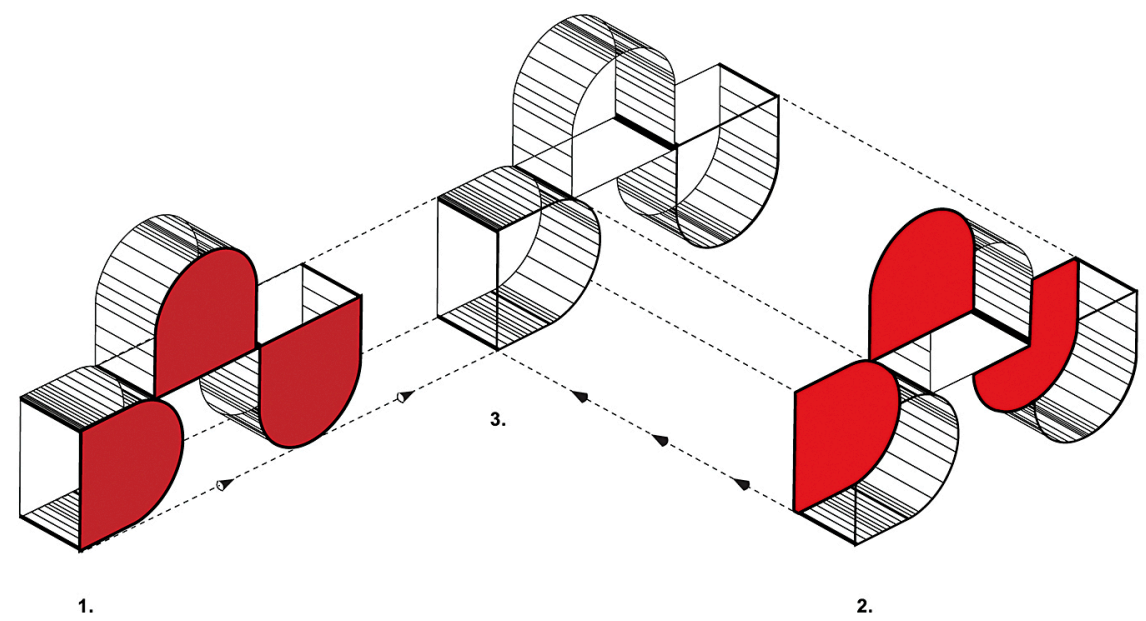

FIGURE 5. Multistable perception of DAU (point 3) from the two conflicting spatial perspectives (points 1 and 2). Conceived and designed by the author. 
collides with the daily reality of the residents of the Institute for whom the Institute is not so much a film set or a fantasy land, but a place of residence and professional activity - in Foucault's terms, "a useful space." "Private space and public space" collide in heterotopia DAU as well, for both are equally exposed to the camera. As the DAU brochure reads, "Freed from protocols of acting scripts and temporal logic, the unprecedented conditions in which DAU was filmed have resulted in a new kind of reality - equally valid, vivid, complex" (Dau Haus 2020a).

The coexistence of this new kind of reality with the fictitious cinematic universe at the same location is only possible within a heterotopia - "the other space." This is crucial for the understanding of the original artistic method through which DAU was conceived, the method that we will be calling heterotopic filmmaking.

\section{HETEROTOPIC FILMMAKING}

For the vast majority of the time, the Institute operated without any cameras rolling, functioning as a purpose-built space for living and working rather than as a film set. When shooting was taking place, however, the film crew had access to any part of the Institute and could start filming its residents at any point. Discretely roaming from one location to another, the camera was attempting to observe and capture both the inhabitants' routine activities as well as sudden moments of drama or crisis (Figure 4). This approach to cinematic production recalls the "life caught unawares" (zhizn'vrasplokh) principle, a filming method devised by the Soviet pioneer filmmaker and cinema theorist Dziga Vertov (1896-1954). Stressing the fact that "all the people must continue to act and function in front of the camera just as they do in everyday life," Vertov described his method of capturing pro-filmic events as one that ensures his film's ontological authenticity and minimises the role of performance (Vertov 1923: 63).

While Vertov and the Russian formalists have arguably conducted "the first sophisticated debate about the proper form and method of making documentary films" (Gershon, Malitsky 2011:56), the history of cinema is rich in examples of the search for verisimilitude; from the post-war Italian Neo-realism to cinéma vérité and directcinema in the '60s, from Cassavetes's and Warhol's experimental films to (to some extent) "Dogme 95" in the " 90 s. What is radically new about Khrajanosvky's method of heterotopic filmmaking, however, is that it represents an attempt to capture reality outside of the real world, a parallel reality of heterotopia, a space that is "simultaneously mythic and real” (Foucault 1967: 17).

In conventional filmmaking, a factual film (documentary, newsreel, etc.) documents real human beings, events, and manifestations of life that take place in the real world. A fictional film (narrative film, art film, etc.) captures scripted performance and staged events that take place in an imaginary on-screen reality. Heterotopic film, however, combines both perspectives: it documents real life, real human beings, and real events from within an imaginary world. Heterotopic filmmaking can therefore be defined as making a factual film in a fictional universe.

\section{HETEROTOPIC VIEWING}

Having defined heterotopic filmmaking, we can now proceed to the discussion of heterotopic viewing and the role of confinement in the spectator's experience of DAU. Ever since Walter Benjamin's seminal 1935 essay "The Work of Art in the Age of Mechanical Reproduction," new media technologies have been associated with the emergence of new ways of apprehending physical reality. To grasp the modalities and parameters of perception that define how a contemporary audience experiences heterotopicallyproduced cinematic content, we suggest the analogy of a stereoscopic device. Dating back to the nineteenth century, the stereoscope mobilizes binocular vision to create an illusion of a three-dimensional image from a pair of two-dimensional ones. Media theorist Jonathan Crary describes a corresponding form of viewing as "an operation 


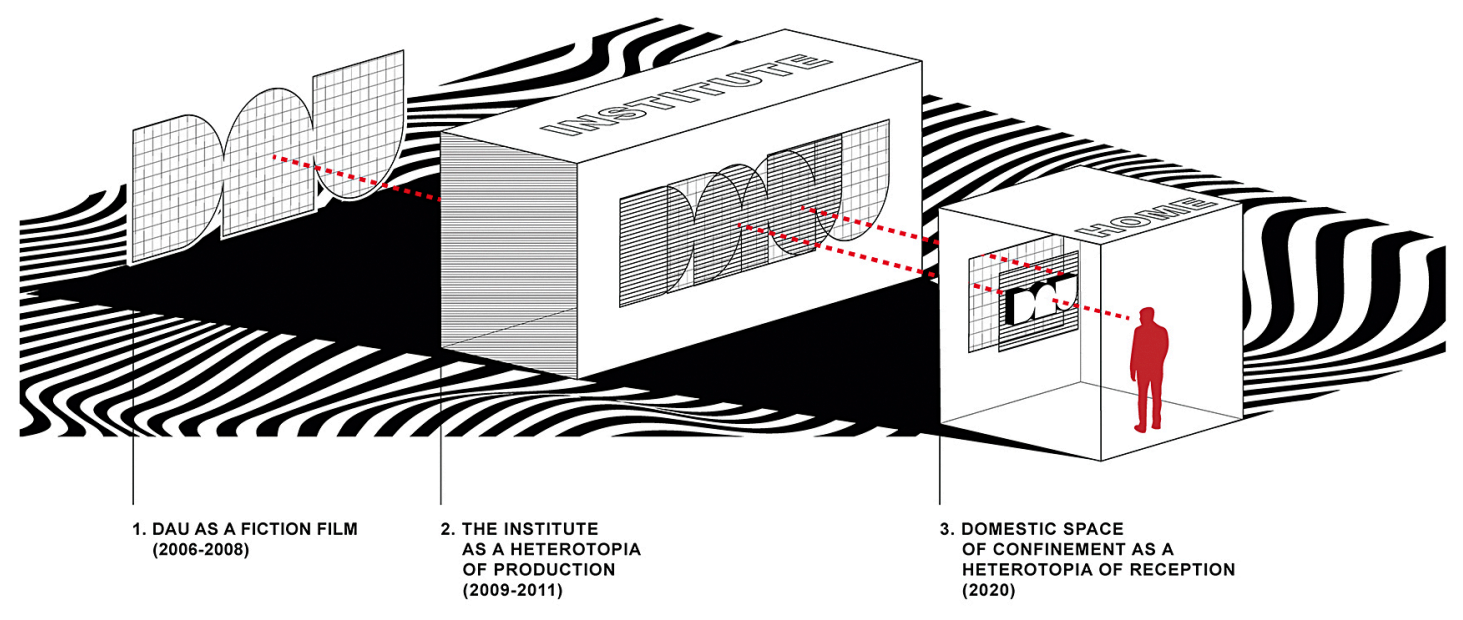

FIGURE 6. Model of production and reception of heterotopic cinema. Conceived and designed by the author. 
of reconciling disparity, of making two distinct views appear as one" (Crary 1992: 120).

Similarly, Khrzhanovsky's heterotopia of production was located at a virtual point of juncture between the cinematic realm of DAU (Figure 6: point 1) and the real-life human existence within the Institute setting (Figure 6: point 2). Like a stereoscopic camera that simultaneously shoots two views of the same scene, Khrzhanovsky's heterotopic filmmaking method documented both the fictional and the factual planes of the DAU project. The "fictional plane" consists of DAU as a biopic/period drama (grid pattern in Figure 6), and the "factual plane" consists of the lived experience of the residents of the Institute (straight-line pattern in

\section{Figure 6).}

Like the stereoscopic effect (whereby two merging optic axes unite slightly different shots of the same scene into a single three-dimensional image) is predicated upon binocular viewing through a stereoscopic device, fully grasping the product of heterotopic filmmaking is only possible from within a heterotopia of reception; a condition that is in and of itself heterotopic, (i.e.), is characterized by a juxtaposition of two disjunct spatialities (Figure 6: point 3). To put it differently, just as a pair of stereoscopic images may be viewed without any specialized device, a heterotopic film can potentially be watched in ordinary nonheterotopic conditions. In both cases, however, the image will appear distorted and the illusion of depth will be lost. [Imagine taking off 3D glasses in the cinema while watching a 3D movie.]

This metaphor, though, is not to be taken literally. While stereoscopic images create an optical illusion, the effect of depth mediated through heterotopia of reception is a multifaceted lived experience. ${ }^{3}$ Heterotopic viewing thus consists of altering the spatio-temporal conditions of perception for the spectator to be able to tune into heterotopic media content created within the altered spatio-temporal conditions of production.

\section{CONCLUSION}

In this final part, we demonstrate how the condition of confinement transforms domestic space into a heterotopia of reception, thus enabling heterotopic viewing of DAU. Quarantine measures enforced by governments worldwide due to the Covid19 pandemic temporarily transformed private households into spaces of confinement (Principles 2 and 6 of heterotopology). Domestic spaces thus acquired the status of "places reserved for individuals who are, in relation to society, in a state of crisis" (Foucault 1967: 18) (Principle 1), access to which is predicated on the "rites of purification" (Principle 5): hand washing, removing the mask, disinfecting personal objects. Furthermore, "spaces of leisure and [those] of work" became indistinguishable due to widespread teleworking (Principle 3). Finally, the way we normally perceive the flow of time in the privacy of our home has also been altered by the pandemic. Usual work and sleep schedules were disturbed, rhythms and cycles staggered, a mix of anxious anticipation and boredom distorted our experience of "clock time" (Principle 4). Taken separately, these manifestations could well be observed in normal life outside of the state of crisis. The presence of all six of them together, however, makes it possible to conclude that in times of pandemic, isolated domestic spaces acquired heterotopic functions.

It now becomes clear how the condition of confinement fits the logic of heterotopic cinema and why DAU - "The first cinematic project about isolation, filmed in isolation" - is indeed meant "for people in isolation," as Khrzhanovsky himself has pointed out (Dau Cinema 2020). The pandemic has transformed domestic space into a heterotopia of reception, providing the spectator with instrumental mediation necessary for heterotopic viewing and allowing $D A U$ to reach its full potential.

In fact, Khrzhanovsky has attempted to artificially create similar heterotopic 


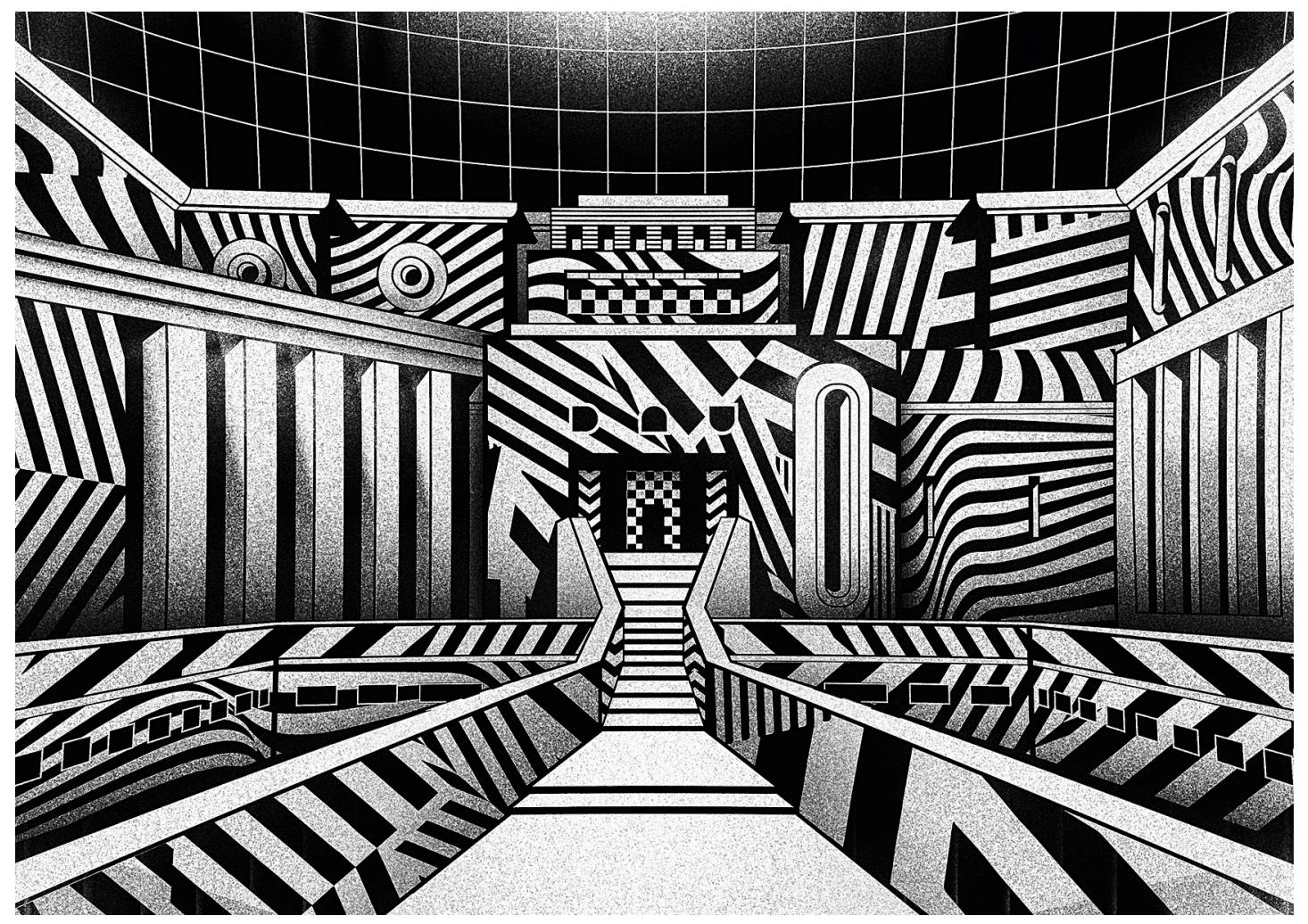

FIGURE 7. Alexandre Zaezjev, Heterotopia DAU (digital graphics, 2020). 
conditions for the reception of his project prior to the pandemic. For the 2019 world premiere in Paris, he transformed two major theatres - Théâtre de la Ville and Théâtre de Châtelet - into a multimedia art space isolated from the outside world by "the General Consulate of DAU" that issued personal visas for the visitors. The filmmaker had also planned to create heterotopias of reception in London and Berlin. The Berlin version, for instance, involved a rebuilding of a part of the Berlin Wall with a goal of closing a whole block on the city's central Unter den Linden Boulevard. Whether or not it will eventually be possible to resume immersive public screenings of DAU, the present paper has demonstrated how the Covid-19 crisis provided Khrzhanovsky with a valuable alternative, thus contributing to the expansion of heterotopic cinema.

\section{REFERENCES}

Arpin-Simonetti, Lisandro 2014. 'The Tulse Luper Suitcases : Peter Greenaway et le "database cinema » les dessous de l'avant-gardisme néo-médiatique.' Hors Champ, 31 December 2014. https://www.horschamp.qc.ca/spip.php?article579 (31 August 2020). Bruno, Giuliana 2002. Atlas of Emotions: Journeys in Art, Architecture, and Film. New York: Verso.

Burlacu, Mihai 2015. 'The Zone as Heterotopia in Andrei Tarkovsky's Stalker'. - Bulletin of the Transilvania University of Braşov 8, 57. http://webbut.unitbv.ro/ BU2015/Series\%20VII/BULETIN\%20I/10_Burlacu.pdf (20 October 2020).

Casetti, Francesco 2015. The Lumière Galaxy. Seven Key Words for the Cinema to Come. New York: Columbia University Press.

Chung, Hye-jin 2018. Media Heterotopias: Digital Effects and Material Labor in Global Film Production. Durham: Duke University Press.

Corbett, Claire 2017. 'Nowhere to run: Repetition compulsion and heterotopia in the Australian postapocalypse - from 'Crabs' to Mad Max'. - Science Fiction Film and Television 10, 3, 329-351.

Crary, Jonathan 1992. Techniques of the Observer: On Vision and Modernity in the Nineteenth Century. London: MIT Press.

Cronk, Jordan 2020. 'DAU. Diary \& Dialogue. Part One: A Living World'. - CinemaScope 83. https://cinemascope.com/cinema-scope-magazine/dau-diary-dialogue-part-one-a-living-world/ (31 August 2020). Dau Cinema 2020. 'About DAU'. https://www.dau.com/ en/about-us (31 August 2020).

Dau Haus 2020a. 'Comme des Garcons DAU Science Booklet Pamphlet Flyer'. https://www.dau.haus/ commedesgarcons-booklet-2018 (31 August 2020). Dau Haus 2020 b. 'Interview with Jürgen Jürges'. https:// www.dau. haus/jurges-interview-2020 (31 August 2020). Dau Haus 2020c. 'Media and Art - Prof. Lev Manovich in conversation with Dr. Ohad Landesman'. https://www. dau.haus/manovich-landesman-2020 (31 August 2020). Dehaene, Michiel; Lieven, De Cauter 2008. Heterotopia and the City: Public Space in a Postcivil Society. New York: Routledge.

Foucault, Michel [1967] 2008. 'Of Other Spaces'. - Trans. Lieven De Cauter, Michiel Dehaene (eds.), Heterotopia and the City: Public Space in a Postcivil Society.

New York: Routledge, 13-28.

Gershon, Ilana; Malitsky, Joshua 2011. 'Documentary Studies and Linguistic Anthropology'. - Culture, Theory and Critique, 52, 1, 45-63.

Groys, Boris 2008. Art Power. Cambridge: MIT Press. Ivakhiv, Adrian 2011. 'Cinema of the Not-Yet: The Utopian Promise of Film as Heterotopia'- - Journal for the Study of Religion, Nature and Culture 5, 2, 186-209. Klein, Sascha 2019. 'A Sealed Rectilinear Planet:The Skyscraper as Vertical Heterot opia in J. G. Ballard's High-Rise and Ben Wheatley's Screen Adaptation'. Space and Culture 1-16.

Knight, Kelvin 2017. Real Places and Impossible Spaces: Foucault Hererotopia in the Fiction of James Joyce, Vladimir Nabokov, and W G Sebald. Norwich:

University of East Anglia.

Knight, Kelvin 2014. 'Placeless places: resolving the paradox of Foucault's heterotopia'. - Textual Practice 31, 1,141-158.

Kuhn, Annette 2004. 'Heterotopia, heterochronia: place and time in cinema memory'. - Screen 45, 2, 106-114. Lappo, Georgy; Polian, Pavel 2007. 'Naoukograds, les villes interdites'. - Christian Jacob (ed.), Lieux de savoir. Espaces et commuanutés, Paris: Albin Michel, 12261249.

Macnab, Geoffrey 2019. ‘DAU: a Never-Ending Experiment in a Soviet Laboratory'. - British Film Institute, 24 January 2019. https://www.bfi.org.uk/ news-opinion/sight-sound-magazine/features/ dau-ilya-khrzhanovsky-report-and-first-look 
(31 August 2020).

Manovich, Lev 2001. The Language of New Media. Cambridge: MIT Press.

Mazierska, Ewa 2012. 'International Co-productions as Productions of Heterotopias'. - Anikó Imre (eds.),

A Companion to Eastern European Cinemas. Hoboken: John Wiley \& Sons.

Näripea, Eva 2013. 'Work in Outer Space: Notes on Eastern European Science Fiction Cinema'. - Ewa Mazierska (eds.), Work in Cinema. New York: Palgrave Macmillan, 209-226.

Näripea, Eva 2014. 'Postcolonial Heterotopias:

A Paracinematic Reading of Marek Piestrak's Estonian Coproductions.' - Ewa Mazierska, Michael Goddard (eds.), Polish Cinema in a Transnational Context. Suffolk: Boydell \& Brewer, 115-133.

Näripea, Eva; Cederlöf, Henriette 2015. 'Genre and Gender in the Dead Mountaineer's Hotel (1979)'. Science Fiction Film and Television 8, 2, 145-166.

Phenomen Trust 2019. 'DAU'. https://www.phenomentrust.org/projects (31 August 2020).

Pinkham, Sophie 2020. 'Nihilism for Oligarchs'. - New Left Review 125, 15 October 2020. https://newleftreview. org/issues/I1125/articles/sophie-pinkham-nihilismfor-oligarchs (20 October 2020).

Smith, Victoria L. 2018. 'The Heterotopias of Todd Haynes: Creating Space for Same Sex Desire in Carol'. Film Criticism 42, 1, March 2018. https://quod.lib. umich.edu/f/fc/13761232.0042.102/--heterotopiasof-todd-haynes-creating-space-for-samesex?rgn=main;view =fulltext (20 October 2020). Sobchack, Vivian 1991. The Address of the Eye: A Phenomenology of Film Experience. Oxford: Princeton University Press.

Vertov, Dziga [1923] 1966. 'O fil'me Kinoglaz'. - Sergey Drobashenko (ed.), Stat'i, dnevniki, zamysli. Moscow: Iskusstvo, 58-74.

Sterzer, Philipp; Kleinschmidt, Andreas; Rees, Geraint 2009. 'The Neural Bases of Multistable Perception'. Trends in Cognitive Sciences, 13, 7, 310-318.

Zhao, Wenqing; Öner, Murat 2018. 'The Cinematic Space in Stephen Daldry's The Hours: A Heterotopian Perspective.' - International Journal of Social

Research 2, 16. https://escipub.com/Articles/IJSR/ IJSR-2018-06-1201 (20 October 2020). 